\title{
Sulfur dioxide emissions from Papandayan and Bromo, two Indonesian volcanoes
}

\author{
P. Bani ${ }^{1,2,3,4}$, Surono ${ }^{4}$, M. Hendrasto ${ }^{4}$, H. Gunawan ${ }^{4}$, and S. Primulyana ${ }^{4}$ \\ ${ }^{1}$ Clermont Université, Université Blaise Pascal, Observatoire de Physique du Globe de Clermont-Ferrand (OPGC), \\ Laboratoire Magmas et Volcans, BP 10448, 63000 Clermont-Ferrand, France \\ ${ }^{2}$ LMV, CNRS, UMR6524, 63038 Clermont-Ferrand, France \\ ${ }^{3} \mathrm{LMV}$, IRD, R 163, 63038 Clermont-Ferrand, France \\ ${ }^{4}$ Center for Volcanology and Geological Hazard Mitigation, Jl Diponegoro No. 57, Bandung, Indonesia
}

Correspondence to: P. Bani (philipson.bani@ird.fr)

Received: 6 April 2013 - Published in Nat. Hazards Earth Syst. Sci. Discuss.: 14 May 2013

Revised: 14 August 2013 - Accepted: 1 September 2013 - Published: 2 October 2013

\begin{abstract}
Indonesia hosts 79 active volcanoes, representing $14 \%$ of all active volcanoes worldwide. However, little is known about their $\mathrm{SO}_{2}$ contribution into the atmosphere, due to isolation and access difficulties. Existing $\mathrm{SO}_{2}$ emission budgets for the Indonesian archipelago are based on extrapolations and inferences as there is a considerable lack of field assessments of degassing. Here, we present the first $\mathrm{SO}_{2}$ flux measurements using differential optical absorption spectroscopy (DOAS) for Papandayan and Bromo, two of the most active volcanoes in Indonesia. Results indicate mean $\mathrm{SO}_{2}$ emission rates of $1.4 \mathrm{td}^{-1}$ from the fumarolic activity of Papandayan and more than $22-32 \mathrm{td}^{-1}$ of $\mathrm{SO}_{2}$ released by Bromo during a declining eruptive phase. These DOAS results are very encouraging and pave the way for a better evaluation of Indonesian volcanic emissions.
\end{abstract}

\section{Introduction}

Volcanic degassing into the atmosphere constitutes one of the external expressions of subsurface magmatic and hydrothermal manifestations. Reciprocally, any changes in the chemical and physical properties of the plume are generally symptomatic of modifications in the magmatic reservoir and/or conduits. Among the volcanic volatile components released into the atmosphere, sulfur dioxide $\left(\mathrm{SO}_{2}\right)$ enhances considerable research interest due to its non-negligible roles in the atmospheric chemistry, atmospheric radiation, hydrological cycle and climate, as well as acidic precipitation and air quality (Charlson et al., 1992; Jones et al., 2001; Penner et al., 2001; Stevenson et al., 2003). It is a relatively abundant species in the volcanic plume, typically in third place behind $\mathrm{H}_{2} \mathrm{O}$ and $\mathrm{CO}_{2}$ with around $5 \mathrm{~mol} \%$ of gas content along with $\mathrm{H}_{2} \mathrm{~S}$ (Shinohara, 2008). $\mathrm{SO}_{2}$ has a very low background level in the atmosphere and strong identifiable optical absorption features in the ultraviolet (UV) skylight region that offer various options for spectroscopic detection in the atmosphere (McGonigle et al., 2003). $\mathrm{SO}_{2}$ is thus a readily measurable species, widely recognized as an important and highly desirable component of multidisciplinary volcano monitoring. Many observatories routinely measure $\mathrm{SO}_{2}$ emission rates in support of their monitoring networks. The global $\mathrm{SO}_{2}$ emission budget estimates over the last four decades range from 1.5 to $40 \mathrm{Tg} \mathrm{yr}^{-1}$ (Table 1) - a very large range due to the diversity of methodology used, the extending number of studied volcanoes and the increasing development of measurement techniques.

According to the IPCC report (2001), the global volcanic $\mathrm{SO}_{2}$ emission budget is highly uncertain, because only very few of the potential sources have been measured and the variability between sources and between different stages of activity is considerable. Over the last ten years, the increasing development in the field of remote sensing has improved our knowledge on the distribution of volcanic volatile sources across the earth and even on the remote and less accessible edifices (McGonigle et al., 2004; Mather et al., 2006; Bani et al., 2012; McCormick et al., 2012). But still many volcanoes on earth have never had their degassing rates evaluated. This 

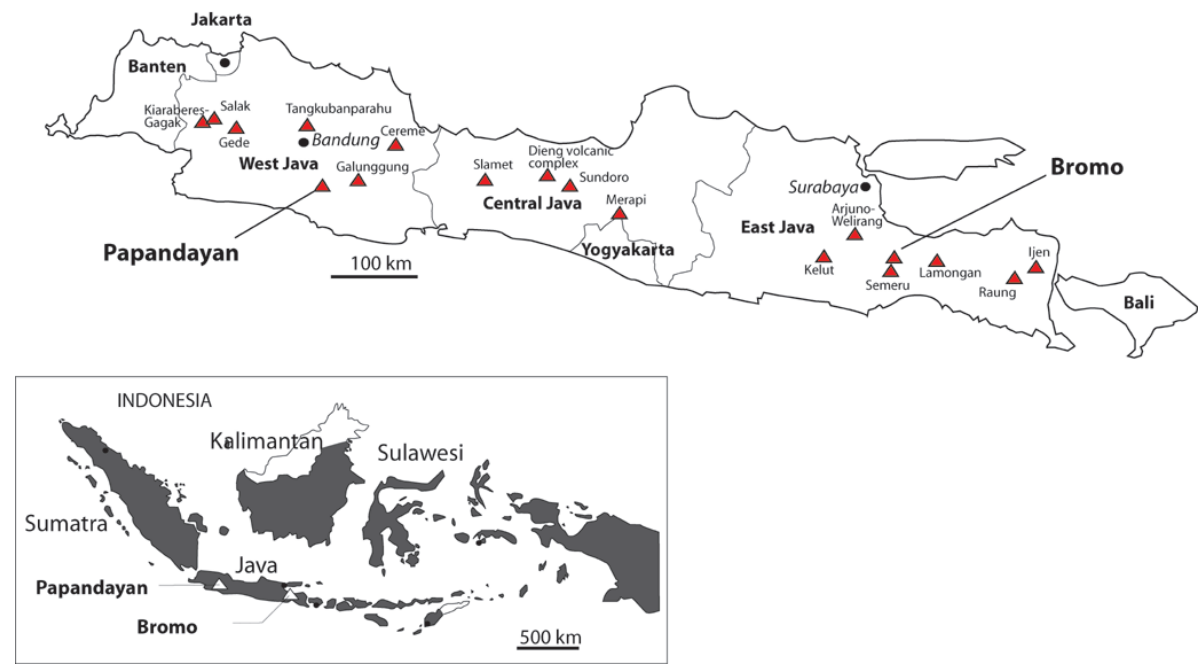

Fig. 1. Java island with its 18 active volcanoes. The target volcanoes, Papandayan and Bromo, are indicated. The location of Java and the studied volcanoes within the Indonesian archipelago is provided below.

is the case in Indonesia where, despite the high number of active volcanoes, the past $\mathrm{SO}_{2}$ emission estimates were based on extrapolation and inference (Nho et al., 1996; Halmer et al., 2002; Hilton et al., 2002), whilst $\mathrm{SO}_{2}$ flux measurements were carried out only on 4 volcanoes (Table 1 ). This present work aims to point out this misrepresentation and further highlight a possibility to constrain the $\mathrm{SO}_{2}$ emission better from Indonesian volcanoes using differential optical absorption spectroscopy (DOAS).

We present $\mathrm{SO}_{2}$ flux measurements, obtained in June 2011 from two volcanoes in Indonesia - including Papandayan and Bromo (Fig. 1), two volcanoes among the most active in Indonesia, and they represent two end-members of volcanic degassing types: a fumarolic emission on Papandayan and an open vent degassing from Bromo

\section{Papandayan and Bromo volcanoes}

Papandayan is a complex stratovolcano culminating $2665 \mathrm{~m}$ above sea level with a base diameter of $\sim 8 \mathrm{~km}$ (Fig. 2) located $45 \mathrm{~km}$ south-southeast of Bandung city, West Java. The edifice became well known after its 1772 eruption that caused the collapse of the northeast flank, leading to a devastating debris avalanche over 250 square kilometers that destroyed about 40 villages and killed nearly 3000 people (Abidin et al., 2006). Papandayan ranks 11th out of the 13 deadliest eruptions on earth (Blong, 1984). Other eruptions have been reported for this volcano in 1882, 1923-1927, 1942, 1993 and 2002 (Abidin et al., 2006). The latest eruption in 2002 is well detailed in Abidin et al. (2006) - about 6000 people were evacuated. Magmatic degassing on Papandayan occurs mainly in two fumarolic zones, aligned in a northwestsoutheasterly direction and located in a deformed, horseshoeshaped eastern crater (Fig. 2) (Mazot et al., 2007, 2008).
Bromo is located $75 \mathrm{~km}$ south of Surabaya, East Java. It occupies the central part of the Tengger caldera - a well-defined and a roughly square structure around $7 \mathrm{~km}$ wide (Fig. 2). The caldera rim culminates at more than $2600 \mathrm{~m}$ above sea level, and the inner caldera floor is around $2100 \mathrm{~m}$ a.s.l. More than 60 explosive eruptions (mainly with $\mathrm{VEI}=2$ ) have been reported to have occurred on Bromo over the past four centuries (source: GVP). However, in contrast to Papandayan, no causalities were reported except for the two tourists killed during the 2004 eruption after venturing too close to the volcano. The present-day active crater, through which magmatic degassing occurs, is Bromo's smallest (500 $\mathrm{m}$ in diameter) and northernmost crater (Fig. 2) (Andres and Kasgnoc, 1998; Nho et al., 1996; GVP Bromo - 03/1995 (BGVN 20:03); GVP Bromo 05/2004 (BGVN 29:05)).

\section{Methods}

$\mathrm{SO}_{2}$ fluxes were measured using a USB2000 ultraviolet spectrometer, and $\mathrm{SO}_{2}$ column amounts were retrieved by following standard DOAS calibration and analysis procedures (Kraus, 2006; Platt and Stutz, 2008). The spectral range of the spectrometer is $280-400 \mathrm{~nm}$ with a spectral resolution of $0.5 \mathrm{~nm}$ FWHM (full width at half maximum). Light entered the spectrometer through a telescope ( $8 \mathrm{mrad}$ FOV) and via a fiber optic bundle. The Vispec program (http:// vispect.sourceforge.net/) was used to field-track the volcanic plume. Total integration times of $3 \mathrm{~s}$ (exposure time $300 \mathrm{~ms}$, 10 co-added spectra) and $1.6 \mathrm{~s}$ (exposure time $200 \mathrm{~ms}, 8 \mathrm{co}-$ added spectra) were applied to Papandayan and Bromo respectively. Reference spectra included in the non-linear fit were obtained by convolving high-resolution $\mathrm{SO}_{2}$ (Bogumil et al., 2003) and $\mathrm{O}_{3}$ (Voigt et al., 2001) cross sections with 
Table 1. $\mathrm{SO}_{2}$ flux contributions from Indonesian volcanoes in the global volcanic emission budgets.

\begin{tabular}{|c|c|c|c|}
\hline Authors & $\begin{array}{l}\text { Global } \mathrm{SO}_{2} \\
\text { emission budget } \\
\left(\mathrm{Tg} \mathrm{yr}^{-1}\right)\end{array}$ & Estimation technique & $\begin{array}{l}\text { Contribution from } \\
\text { Indonesian volcanoes. }\end{array}$ \\
\hline Kellogg et al. (1972) & 1.5 & $\begin{array}{l}\mathrm{SO}_{2} \text { emission budget deduced from the volume of } \\
\text { erupted lava and assuming that } \mathrm{SO}_{2} \text { constitutes } 0.5 \% \\
\text { of the erupted gas. }\end{array}$ & $\begin{array}{l}\mathrm{SO}_{2} \text { contribution from } \\
\text { Indonesian volcanoes not } \\
\text { specified. }\end{array}$ \\
\hline Cadle (1975) & 7.5 & $\begin{array}{l}\mathrm{SO}_{2} \text { emission budget deduced from the volume of } \\
\text { erupted lava and assuming that } \mathrm{SO}_{2} \text { constitutes } 2.5 \% \\
\text { of the erupted gas. }\end{array}$ & $\begin{array}{l}\mathrm{SO}_{2} \text { contribution from } \\
\text { Indonesian volcanoes not } \\
\text { specified. }\end{array}$ \\
\hline Le Guern (1982) & $5-10$ & $\begin{array}{l}\mathrm{SO}_{2} \text { budget estimation was based on lava density, gas } \\
\text { content and viscosity. }\end{array}$ & $\begin{array}{l}0.073 \mathrm{Tg} \mathrm{yr}^{-1} \text { from } \\
\text { Indonesia (only Merapi } \\
\text { volcano was considered in } \\
\text { this estimation). }\end{array}$ \\
\hline $\begin{array}{l}\text { Berresheim and } \\
\text { Jaeschke (1983) }\end{array}$ & 15.3 & $\begin{array}{l}\mathrm{SO}_{2} \text { emission budget obtained from a classification of } \\
\text { volcanic activities in the literature. }\end{array}$ & $\begin{array}{l}\mathrm{SO}_{2} \text { contribution from } \\
\text { Indonesian volcanoes not } \\
\text { specified. }\end{array}$ \\
\hline Stoiber et al. (1987) & 18.7 & $\begin{array}{l}\text { Based on } 35 \text { volcanoes monitored by COSPEC and } \\
\text { questionnaire sent to volcanologists to estimate plume } \\
\text { sizes, from which } \mathrm{SO}_{2} \text { burdens were } \\
\text { calculated. }\end{array}$ & $\begin{array}{l}\mathrm{SO}_{2} \text { contribution from } \\
\text { Indonesian volcanoes not } \\
\text { specified. }\end{array}$ \\
\hline Spiro et al. (1992) & 19.2 & $\begin{array}{l}\mathrm{SO}_{2} \text { budget estimation derived from the Volcanic } \\
\text { Explosivity Index (VEI) with data from Simkin et } \\
\text { al. (1981) and as function of location (at convergent } \\
\text { plate margin or not). For some volcanoes, estimations } \\
\text { were derived from plume size. }\end{array}$ & $\begin{array}{l}0.41 \mathrm{Tg} \mathrm{yr}^{-1} \text { attributed to } \\
\text { Indonesian volcanoes. }\end{array}$ \\
\hline $\begin{array}{l}\text { Andres and Kasgnoc } \\
\text { (1998) }\end{array}$ & 13 & $\begin{array}{l}\text { Data from TOMS and COSPEC, as well as data from } \\
\text { journals, conferences and personal communication. }\end{array}$ & $\begin{array}{l}\text { Indonesian volcanoes } \\
\text { contributed only } \\
0.10 \mathrm{Tg} \mathrm{yr}^{-1} \text { ( } 3 \text { volcanoes were } \\
\text { considered, including Merapi, } \\
\text { Tangkuban Parahu, Bromo } \\
\text { and Slamet). }\end{array}$ \\
\hline Graf et al. (1997) & 34.9 & $\begin{array}{l}\mathrm{SO}_{2} \text { emission budget derived from atmospheric } \\
\text { circulation-chemistry model. }\end{array}$ & $\begin{array}{l}\mathrm{SO}_{2} \text { emissions not specified } \\
\text { for Indonesia. However the } \\
\text { authors indicate strong } \\
\text { sulfate burden over the } \\
\text { archipelago. }\end{array}$ \\
\hline Halmer et al. (2002) & $15-21$ & $\begin{array}{l}\mathrm{SO}_{2} \text { emission budget based on } 360 \text { explosively de- } \\
\text { gassing subaerial volcanoes, of which } 50 \text { were mon- } \\
\text { itored directly by TOMS and/or COSPEC; the sulfur } \\
\text { emission of the remaining } 310 \text { volcanoes was extrap- } \\
\text { olated. }\end{array}$ & $\begin{array}{l}2.1-2.6 \mathrm{Tg} \mathrm{yr}^{-1} \text { attributed to } \\
\text { Indonesia subduction zone. }\end{array}$ \\
\hline Diehl et al. (2012) & 26 & $\begin{array}{l}\mathrm{SO}_{2} \text { emission budget is derived using the Volcanic } \\
\text { Sulfur Index (VSI) and based on } 1167 \text { volcanoes con- } \\
\text { sidered to be active in the Global Volcanism Program } \\
\text { from } 1979 \text { to } 2009 \text {. Data are replaced by specific ob- } \\
\text { servation from TOMS and OMI when available or in } \\
\text { some cases with COSPEC measurements and more } \\
\text { detailed analyses from open literature. }\end{array}$ & $\begin{array}{l}\mathrm{SO}_{2} \text { emissions not specified } \\
\text { for Indonesian archipelago. }\end{array}$ \\
\hline
\end{tabular}

the instrument line shape. A Fraunhofer reference spectrum and ring spectrum, calculated in DOASIS, were also included in the fit. The optimum fitting windows of $302-325 \mathrm{~nm}$ and 300-320 nm for Papandayan and Bromo respectively were evaluated by obtaining a near random fit residual with minimum deviation. Figures 3 and 5 show examples of the $\mathrm{SO}_{2}$ fit. Each spectrum position was determined from a continuously recording GPS unit. Wind speeds were obtained using a handheld anemometer at high points, to the east of the Tengger caldera rim for Bromo and about $200 \mathrm{~m}$ above the northern fumarole zone on Papandayan. On this latter volcano, DOAS $\mathrm{SO}_{2}$ flux measurements were performed in 


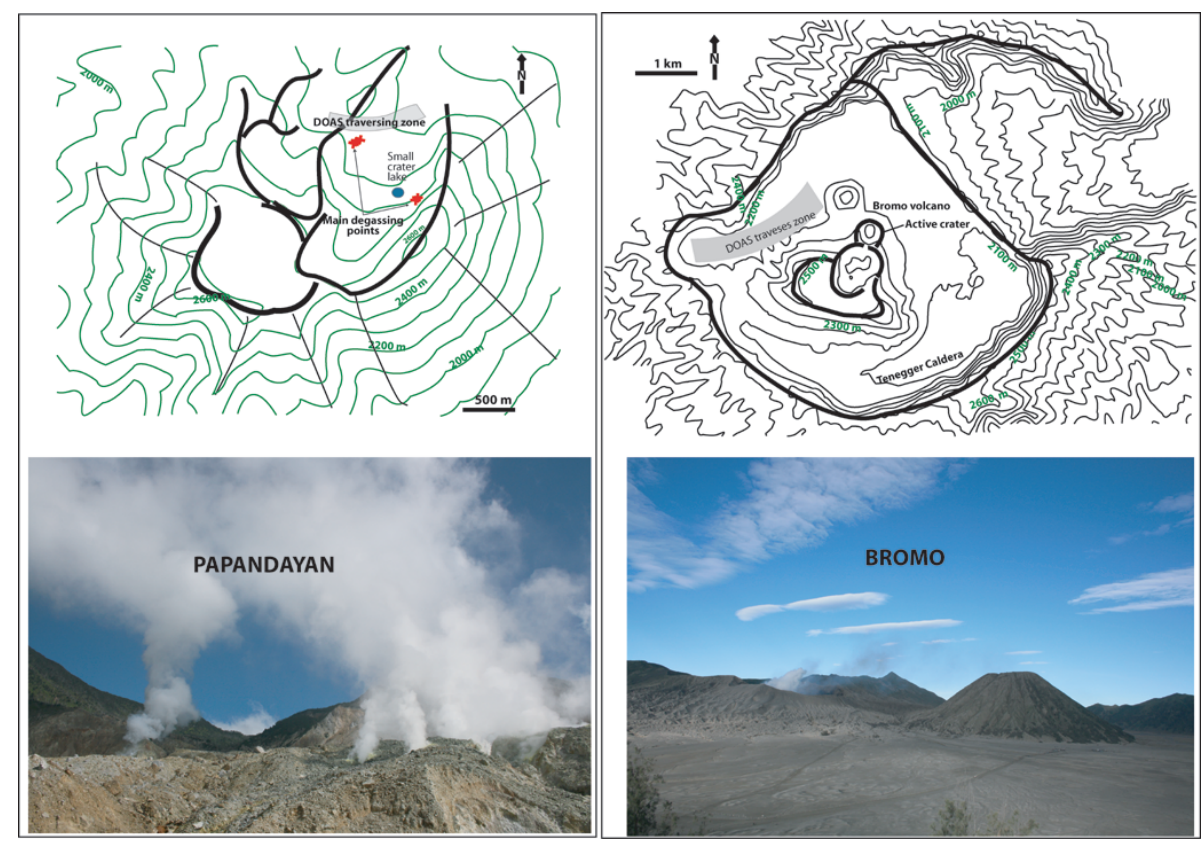

Fig. 2. Maps of the Papandayan summit and the Bromo caldera. The DOAS traverse zones are shaded in gray. The main degassing points are shown: fumarole zones on Papandayan and the active crater on Bromo. Pictures provide a synoptic view of degassing during the field measurements.

walking-traverse mode (McGonigle et al., 2002). The spectrometer was carried with the telescope pointing to the zenith while walking across the northern part of the eastern crater (Fig. 2). The plume was drifting to the northwest at the time of measurement. A complementary USB4000 spectrometer was positioned on a fixed mode, operating within the 292$446 \mathrm{~nm}$ spectral range and with 0.3 FWHM spectral resolution. $\mathrm{SO}_{2}$ column amounts were retrieved using the same procedures as for the USB2000. On Bromo, access into the caldera was possible using a $4 \mathrm{WD}$ vehicle, so DOAS traverses were done on a vehicle (Fig. 2). During measurement, the wind was from the east, forcing the plume partially above the inaccessible relief zone to the west (Fig. 2). To ensure measurements across the entire plume, the telescope was positioned with an inclination of around $30^{\circ}$ from the zenith.

\subsection{Errors in the $\mathrm{SO}_{2}$ flux measurements}

Error in the $\mathrm{SO}_{2}$ flux measurements is derived from four different factors, including the retrieved column amount, the distance perpendicular to the plume transport direction, the angle between the assumed wind direction and the traverse path and the plume transport speed (Mather et al., 2006). Error in the retrieved $\mathrm{SO}_{2}$ column amount depends on many factors (Stutz and Platt, 1996; Hausmann et al., 1999; Kern et al., 2010), but we assume that the dominant error is induced by variable cloudiness that we compensate using artificial constant dark, calculated from each recorded spectrum, in the range of blind pixel (pixel below $290 \mathrm{~nm}$ ) (Tsanev, 2008). Such corrections account for dark spectrum, offset and stray light. We estimate that the error in the column amount contributes $0.006-0.014$ to the squared variation coefficient of the total flux, whilst error contributions from the distance traversed perpendicular to the plume and from the assumed wind direction following the approached detailed in Mather et al. (2006) are 0.001-0.006 and $\sim 0.003$ respectively. Note however that all these errors are negligible in comparison to uncertainties in the plume speed (e.g., Stoiber et al., 1983). We assumed that the plume transport speed is conservative throughout our measurements period with a relative error of $\sim 30-35 \%$, consistent with Stoiber et al. (1983).

\section{Results and discussion}

The DOAS measurements obtained in this work are summarized in Table 2, while Figs. 4 and 5 display plots of all traverses and static measurements. Non-linear fits of recorded spectra under Bromo and Papandayan highlight strong $\mathrm{SO}_{2}$ signals in the plume (Figs. 3 and 5) with maximum concentrations largely exceeding $100 \mathrm{ppm} . \mathrm{m}$ above the background level. It is therefore evident at this stage that Papandayan and Bromo release $\mathrm{SO}_{2}$ into the atmosphere.

\subsection{Papandayan's $\mathrm{SO}_{2}$ emission rate}

Results indicate that $\mathrm{SO}_{2}$ emission rate on Papandayan fluctuates between $0.4 \pm 0.1$ and $2.8 \pm 0.8 \mathrm{t} \mathrm{d}^{-1}$ with a mean value of $1.4 \pm 0.5 \mathrm{td}^{-1}$. This fluctuation is consistent with DOAS static measurements (Fig. 4) where the $\mathrm{SO}_{2}$ column amount 


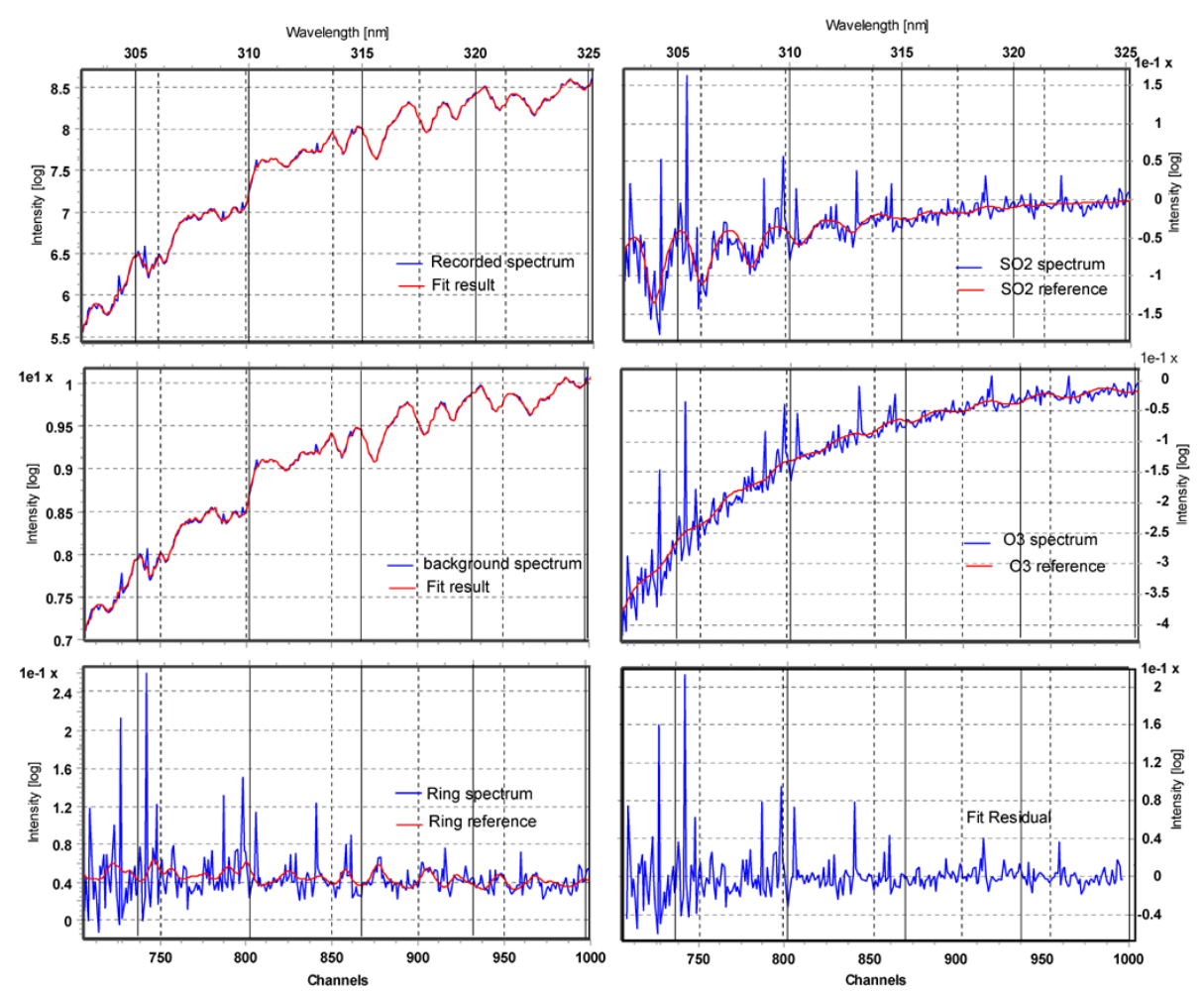

Fig. 3. Example of DOAS $\mathrm{SO}_{2}$ fit on Papandayan. Blue lines are recorded spectra. The background spectra were acquired by pointing outside the plume.

Table 2. Estimated $\mathrm{SO}_{2}$ emission rates for Papandayan and Bromo.

\begin{tabular}{|c|c|c|c|c|c|c|c|c|}
\hline Volcano & $\begin{array}{l}\text { State of activity } \\
\text { during measurements }\end{array}$ & $\begin{array}{l}\text { Date of } \\
\text { measurements }\end{array}$ & Traverse & $\begin{array}{l}\text { Start time }(\mathrm{UT}) \\
\text { local time }= \\
\mathrm{UT}+7\end{array}$ & $\begin{array}{l}\text { Mean measurement } \\
\text { distance from } \\
\text { sources }(\mathrm{km})\end{array}$ & $\begin{array}{l}\text { Plume } \\
\text { width }(\mathrm{km})\end{array}$ & $\begin{array}{l}\text { Average column } \\
\text { amount } \\
\left(\mathrm{mg} \mathrm{m}^{-2}\right)\end{array}$ & $\begin{array}{l}\mathrm{SO}_{2} \text { flux } \\
\left(\mathrm{td}^{-1}\right)\end{array}$ \\
\hline Papandayan & Degassing through fumaroles & $18 / 06 / 11$ & Trav_1 & 06:47:04 & 0.6 & 0.14 & 37 & $0.4 \pm 0.1$ \\
\hline Trav_2 & $06: 51: 03$ & 0.5 & 0.11 & 110 & $1.2 \pm 0.4$ & & & \\
\hline Trav_3 & $06: 56: 45$ & 0.6 & 0.11 & 110 & $1.2 \pm 0.4$ & & & \\
\hline Trav_4 & $06: 59: 51$ & 0.5 & 0.10 & 114 & $1.2 \pm 0.4$ & & & \\
\hline Trav_5 & 07:04:35 & 0.5 & 0.12 & 200 & $2.8 \pm 0.8$ & & & \\
\hline \multirow[t]{2}{*}{ Trav_6 } & 07:08:11 & 0.5 & 0.11 & 209 & $2.2 \pm 0.7$ & & & \\
\hline & & & & & & \multicolumn{3}{|c|}{ Mean $\mathrm{SO}_{2}$ emission rate $=1.4 \pm 0.5 \mathrm{t} \mathrm{d}^{-1}$} \\
\hline Bromo & Open vent degassing & $23 / 06 / 11$ & Trav_1 & 03:11:58 & 2.3 & 0.30 & 49 & $2.4 \pm 0.8$ \\
\hline Trav_2 & $03: 20: 48$ & 2.3 & $0.75^{-}$ & 120 & $32.1 \pm 11.2$ & & & \\
\hline Trav_3 & 03:32:50 & 2.3 & 0.14 & 54 & $0.7 \pm 0.2$ & & & \\
\hline Trav_4 & 03:37:20 & 2.3 & 0.68 & 79 & $22.0 \pm 7.7$ & & & \\
\hline \multirow[t]{2}{*}{ Trav_5 } & $03: 49: 23$ & 2.3 & 0.16 & 30 & $0.7 \pm 0.2$ & & & \\
\hline & & & & & & \multicolumn{3}{|c|}{ Mean $\mathrm{SO}_{2}$ emission rate $=27.1 \pm 9.5 \mathrm{t} \mathrm{d}^{-1}$} \\
\hline
\end{tabular}

The mean emission rate is deduced from traverses 2 and 4 (in bold), whose profiles are closer to the real degassing of Bromo. Traverses 1, 3 and 5 account for a small portion of the plume (see text for further detail).

increased progressively from $\sim 40 \mathrm{ppm} . \mathrm{m}$ to $\sim 140 \mathrm{ppm} . \mathrm{m}$ over a period of $30 \mathrm{~min}$ before dropping to the background level in the following $15 \mathrm{~min}$. The $\mathrm{SO}_{2}$ flux increased accordingly in traverses 1 to 5 and then decreased in traverse 6. Further measurements are required to delimit Papandayan emissions better. However, it is likely that changes in Papandayan's $\mathrm{SO}_{2}$ emission rate come from subsurface magmatic-hydrothermal processes with regular magmatic gas discharges pumping up to $0.03 \mathrm{~kg} \mathrm{SO}_{2} \mathrm{~s}^{-1}$ into the atmosphere. In any case, Papandayan's $\mathrm{SO}_{2}$ contribution to the atmosphere is relatively small compared to other volcanic sources (Andres and Kasgnoc, 1998). Assuming that the DOAS results are representative, this volcano releases only about 500 tons of sulfur dioxide into the atmosphere annually. This low $\mathrm{SO}_{2}$ release into the atmosphere is expected for fumarolic-type activity. Mazot et al. (2008) provide a 

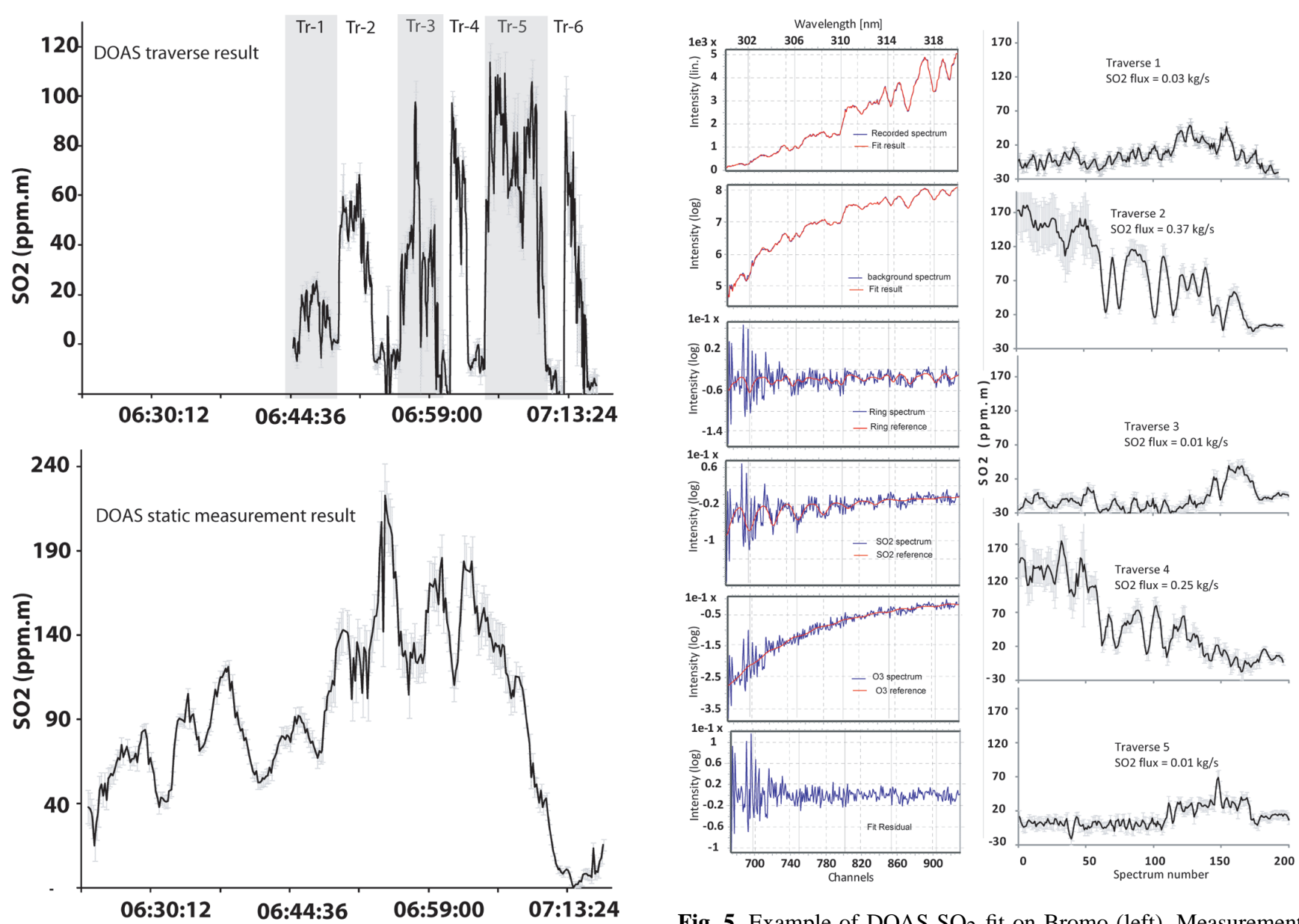

Fig. 5. Example of DOAS $\mathrm{SO}_{2}$ fit on Bromo (left). Measurement spectra are blue. Traverse measurement profiles are shown (right). Traverses 1, 3 and 5 did not catch the bulk concentration while traverses 2 and 4 commenced in the plume (see text). results obtained on Papandayan. Time axes were aligned highlighting the increase of $\mathrm{SO}_{2}$ column amounts in both static and traverse measurements.

compilation of Papandayan gas chemistry, and mean $\mathrm{SO}_{2}$ concentration $(0.11 \mathrm{~mol} \%)$ is significantly lower than $\mathrm{H}_{2} \mathrm{~S}$ concentration $(0.51 \mathrm{~mol} \%)$. Assuming that these concentrations are representative, and using the $\mathrm{H}_{2} \mathrm{~S} / \mathrm{SO}_{2}$ molar ratio of 4.6, the $\mathrm{H}_{2} \mathrm{~S}$ emission rate from Papandayan can be estimated at around $3.4 \mathrm{td}^{-1}$, more than twice the $\mathrm{SO}_{2}$ emission rate. According to experimental studies and thermochemical modeling of volatile partitioning between vapor and liquid in two-phase hydrothermal systems, $\mathrm{CO}_{2}$ is the most abundant hydrothermal gas followed by $\mathrm{H}_{2} \mathrm{~S}-$ other sulfurous gases are negligible (Symonds et al., 2001; Drummond and Ohmoto, 1985; Giggenbach, 1980; Reed and Spycher, 1984, 1985; Spycher and Reed, 1989). The strong availability of $\mathrm{H}_{2} \mathrm{~S}$ suggests the existence of active hydrothermal processes beneath Papandayan's fumarolic activity, and that a portion of the $\mathrm{SO}_{2}$ released from the magmatic source probably sinks out by hydrolysis $\left(4 \mathrm{SO}_{2}+4 \mathrm{H}_{2} \mathrm{O}\right.$ $=\mathrm{H}_{2} \mathrm{~S}+3 \mathrm{H}_{2} \mathrm{SO}_{4}$ and $3 \mathrm{SO}_{2}+2 \mathrm{H}_{2} \mathrm{O}=\mathrm{S}+2 \mathrm{H}_{2} \mathrm{SO}_{4}$ ) (Holland, 1965) or is trapped by other hydrothermal processes.

Consequently, when considering $\mathrm{SO}_{2}$ flux measurements for monitoring purposes, the existence of hydrothermal processes should be taken into account. Alternatively, $\mathrm{H}_{2} \mathrm{~S}$ may be a good candidate for monitoring as suggested by Symonds et al. (2001) and Aiuppa et al. (2005). In any case, the DOAS measurement results highlight the potential of $\mathrm{SO}_{2}$ monitoring of this fumarolically active volcano, and the $1.4 \mathrm{td}^{-1}$ of $\mathrm{SO}_{2}$ released into the atmosphere can henceforth be used as a baseline for future $\mathrm{SO}_{2}$ flux measurements.

\subsection{Bromo's $\mathrm{SO}_{2}$ emission rate}

The $\mathrm{SO}_{2}$ flux measurements from Bromo vary roughly between $0.7 \pm 0.2 \mathrm{td}^{-1}$ and $32 \pm 11.2 \mathrm{td}^{-1}$, but unlike the Papandayan survey, there were no static measurements to support this investigation. Furthermore, despite the strong signal obtained in the $\mathrm{SO}_{2}$ fit procedure (Fig. 5), all the traverses were not completed (Fig. 5), and $\mathrm{SO}_{2}$ fluxes for traverses 1,3 and 5 were dramatically reduced in comparison to traverses 2 and 4 . The reason for this disparity was the inclination of the 


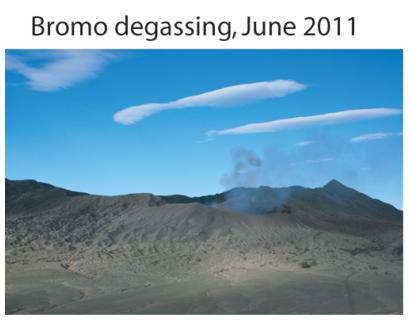

Bromo active vent, May 2012

Fig. 6. Bromo degassing observed during two different periods. In June 2011 (left), during measurement, the degassing was clearly visible $2 \mathrm{~km}$ from the volcano. In May 2012, there was no plume on Bromo and no $\mathrm{SO}_{2}$ detected by DOAS. Only a stagnate white vapor was observed in the active crater (right).

telescope since part of the plume dispersed above the western relief (Fig. 2). Traverses 2 and 4 commenced below the plume, but the relief configuration precluded a complete profile across the plume, while traverses 1,3 and 5 began away from the plume, and the telescope inclination was not sufficient to catch the bulk plume concentration when the vehicle reached the relief. The outcome of these DOAS $\mathrm{SO}_{2}$ flux measurements may not be representative of the volcano's activity at the time of the survey. However, in the configuration described above, the measurements from traverses 2 and 4 are much closer to reality, suggesting an $\mathrm{SO}_{2}$ flux of more than $22-32 \mathrm{td}^{-1}$. In the past, the $\mathrm{SO}_{2}$ emission rate of this volcano was estimated during two eruptive periods: on 8 27 March 1995 (6, 22 and $\left.22 \mathrm{t} \mathrm{d}^{-1}\right)$ (GVP, 03/1995 - BGVN 20:03) and on 14 June $2004\left(200 \mathrm{td}^{-1}\right)(\mathrm{GVP}, 05 / 2004-$ BGVN 29:05). The $\mathrm{SO}_{2}$ fluxes published in Andres and Kagnoc's (1998) well-known paper were derived from the March 1995 COSPEC measurements as no DOAS results exist prior to this work. Our DOAS measurements were carried out in June 2011 after a strong eruptive phase that commenced in November 2010 and persisted until April 2012. Thus, our results likely reflect the continuous decline of the eruptive phase. In May 2012, a second DOAS survey was organized on Bromo, but, surprisingly, the results showed no $\mathrm{SO}_{2}$ emission from the active crater (Fig. 6). Bromo is therefore not a persistent source of $\mathrm{SO}_{2}$ in the atmosphere, as widely thought. However, this volcano has a high frequency of eruptive activity - about one eruption every 6-7 yr since 1804 (http://www.volcano.si.edu/index.cfm), which indicates that it is nevertheless a major contributor of $\mathrm{SO}_{2}$ to the atmosphere. Regular measurements over a period of 6-7 yr are necessary to determine the $\mathrm{SO}_{2}$ emission rate of this volcano better. In any case, this work highlights the potential for DOAS traverses on Bromo and encourages systematic DOAS deployment for monitoring and degassing studies given the short periodicity of eruptive events.

\section{Conclusions}

We present the first DOAS $\mathrm{SO}_{2}$ flux estimates for Papandayan and Bromo, two of the most active volcanoes in Indonesia. Results indicate mean $\mathrm{SO}_{2}$ emission rates of $1.4 \mathrm{td}^{-1}$ from Papandayan's fumarolic activity and more than $22-32 \mathrm{td}^{-1}$ of $\mathrm{SO}_{2}$ released by Bromo during a declining eruptive phase. Results further indicate that Papandayan's $\mathrm{SO}_{2}$ release is sustained by the regular discharge of gas, although much of the $\mathrm{SO}_{2}$ is likely trapped by subsurface hydrothermal processes, leading to significant release of $\mathrm{H}_{2} \mathrm{~S}$ into the atmosphere. Bromo's $\mathrm{SO}_{2}$ releases appear not to be persistent over time. This volcano is nevertheless a major source of volcanic degassing into the atmosphere given its 6-7 yr cycle of periodic eruptive activity. In contrast, the permanent degassing on Papandayan represents a negligible contribution of $\mathrm{SO}_{2}$ to the atmosphere outside eruptive periods. Finally, the DOAS measurements obtained on Papandayan and Bromo are very encouraging given the numerous volcanoes in Indonesia whose degassing has never been evaluated. In addition, this work establishes benchmarks for $\mathrm{SO}_{2}$ flux monitoring on both Bromo and Papandayan.

Acknowledgements. We acknowledge technical assistance from Bromo and Papandayan observatories. Field work was supported by IRD and CVGHM. We appreciate support from IFI.

Edited by: A. Costa

Reviewed by: P. Allard and two anonymous referees

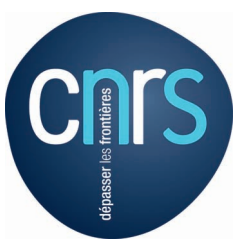

The publication of this article is financed by CNRS-INSU.

\section{References}

Abidin, H. Z., Andreas, H., Suganda, O. K., Meilano, I., Hendrasto, M., Kusuma, M. A., Darmawan, D., Purbawinata, M. A., Wirakusumah, A. D., and Kimata, F.: Ground deformation of Papandayan volcano before, during, and after the 2002 eruption as detected by GPS surveys, B. Volcanol., 10, 75-84, doi:10.1007/s10291-005-0009-1, 2006.

Aiuppa, A., Inguaggiato, S., McGonigle, A. J. S., O’Dwyer, M., Oppenheimer, C., Padgett, M. J., Rouwet, D., and Valenza, M.: $\mathrm{H}_{2} \mathrm{~S}$ fluxes from Mt. Etna, Stromboli, and Vulcano (italy) an implications for the sulfur budget at volcanoes, Geochim. Cosmochim. Ac., 69, 1861-1871, 2005.

Andres, R. J. and Kasgnoc, A. D.: A time-average inventory of subaerial volcanic sulfur emissions, J. Geophys. Res., 103, 2525125261, 1998.

Bani, P., Oppenheimer, C., Allard, P., Shinohara, H., Tsanev, V., Carn, S., Lardy, M., and Garaebiti, E.: First estimate of volcanic 
$\mathrm{SO}_{2}$ budget for Vanuatu island arc, J. Volcanol. Geoth. Res., 211-212, 36-46, 2012.

Berresheim, H. and Jaeschke, W.: The contribution of volcanoes to the global atmospheric budget, J. Geophys. Res., 88, 3732-3740, 1983.

Blong, J. R.: Volcanic hazards: a sourcebook on the effects of eruptions. Academic Press, University of California, 424 pp., 1984.

Bogumil, K., Orphal, J., Homann, T., Voigt, S., Spietz, P., Fleischmann, O. C., Vogel, A., Hartmann, M., Kromminga, H., Bovensmann, H., Frerick, J., and Burrows, J. P.: Measurements of molecular absorption spectra with the SCIAMACHY preflight model: instrument characterization and reference data for atmospheric remotesensing in the $230-2380 \mathrm{~nm}$ region, J. Photoch. Photobio. A, 157, 167-184, 2003.

Cadle, R. D.: Volcanic emissions of halides and sulfur compounds to troposphere and stratosphere, J. Geophys. Res., 88, 1650$1652,1975$.

Charlson, R. J., Schwartz, S. E., Hales, J. K., Cess, R. D., Coakley, J. A., Hasen, J. E., and Hoffman, D. J.: Climate forcing by anthropogenic aerosols, Science, 255, 422-430, 1992.

Diehl, T., Heil, A., Chin, M., Pan, X., Streets, D., Schultz, M., and Kinne, S.: Anthropogenic, biomass burning, and volcanic emissions of black carbon, organic carbon, and $\mathrm{SO}_{2}$ from 1980 to 2010 for hindcast model experiments, Atmos. Chem. Phys. Discuss., 12, 24895-24954, doi:10.5194/acpd-12-24895-2012, 2012.

Drummond, S. E. and Ohmoto, H.: Chemical evolution and mineral deposition in boiling hydrothermal systems, Econ. Geol., 80, 126-147, 1985.

Giggenbach, W. F.: Geothermal gas equilibria, Geochim. Cosmochim. Ac., 44, 2021-2032, 1980.

Graf, H.-F., Feichter, J., and Langmann, B.: Volcanic sulfur emissions: estimates of source strength and its contribution to the global sulfate distribution, J. Geophys. Res., 102, 10727-10738, 1997.

Halmer, M. M., Schmincke, H.-F., and Graf, H.-F.: The annual volcanic gas input into the atmosphere, in particular into the stratosphere: a global data set for the past 100 years, J. Volcanol. Geoth. Res., 115, 511-528, 2002.

Hausmann, M., Brandenburger, U., Brauers, T., and Dorn, H.-P.: Simple Monte Carlo methods to estimate the spectra evaluation error in differential-optical-absorption spectroscopy, Appl. Optics, 36, 463-475, 1999.

Hilton, D. R., Fischer, T. P., and Marty, B.: Noble Gases and Volatile Recycling at Subduction Zones, Rev. Mineral. Geochem., 47, 319-370, doi:10.2138/rmg.2002.47.9, 2002.

Holland, H. D.: Some applications of thermochemical data to problems of ore deposits II. Mineral assemblages and the composition of ore-forming fluids, Econ. Geol., 60, 1101-1166, 1965.

IPCC: Intergovernmental Panel on Climate Change Working group (IPCC Report), Climate change 2001: The Scientific Basis, Contribution of Working Group I to the Third Assessment Report of the Intergovernmental Panel on Climate Change, edited by: Houghton, J. T., Ding, Y., Griggs, D. J., Noguer, M., Van der Liden, P. J., and Xiaosu, D., 2001.

Jones, A., Robert, D. L., Woodage, M. J., and Johnson, C. E.: Indirect sulphate aerosol forcing in a climate model with an interactive sulphur cycle, J. Geophys. Res., 106, 20293-20310, 2001.
Kellogg, W. W., Cadle, R. D., Allen, E. R., Lazrus, A. L., and Martell, E. A.: The sulfur cycle, Science, 175, 587-596, 1972.

Kern, C., Deutschmann, T., Vogel, L., Wohrbach, M., Wagner, T., and Platt, U.: Radiative transfer corrections for accurate spectroscopic measurements of volcanic gas emissions, B. Volcanol., 72, 233-247, doi:10.1007/s00445-009-0313-7, 2010.

Kraus, S.: DOASIS - A framework design for DOAS, Shaker Verlag, Aachen, 184 pp., 2006.

LeGuern, F.: Les débits de $\mathrm{CO}_{2}$ et de $\mathrm{SO}_{2}$ volcaniques dans l'atmosphère, B. Volcanol., 45, 197-202, 1982.

Mather, T. A., Pyle, D. M., Tsanev, V. I., McGonigle, A. J. S., Oppenheimer, C., and Allen, A. G.: A reassessment of current volcanic emissions from the Central American arc with specific examples from Nicaragua, J. Volcanol. Geoth. Res., 149, 297-311, 2006.

Mazot, A., Bernard, A., and Supriatman, I. S.: Hydrothermal system of the Papandayan Volcano, West Java, Indonesia and its geochemistry evolution of thermal water after the November 2002 eruption, Jurnal Geologi Indonesia, 2, 15-29, 2007.

Mazot, A., Bernard, A., Fischer, T., Inguaggiato, S., and Sutawidjaja, I. S.: Chemical evolution of thermal waters and changes in the hydrothermal system of Papandayan volcano (West Java, Indonesia) after the November 2002 eruption, J. Volcanol. Geoth. Res., 178, 276-286, 2008.

McCormick, B. T., Edmonds, M., Mather, T. A., and Carn, S. A.: First synoptic analysis of volcanic degassing in Papua New Guinea, Geochem. Geophys. Geosyst., 13, Q03008, doi:10.1029/2011GC003945, 2012.

McGonigle, A. J. S., Oppenheimer, C., Galle, B., Mather, T. A., and Pyle, D. M.: Walking traverse and scanning DOAS measurements of volcanique gas emission rates, Geophys. Res. Lett., 29, 1985, doi.10.1029/2002GL015827, 2002.

McGonigle, A. J. S., Oppenheimer, C., Hayes, A. R., Galle, B., Edmonds, M., Caltabiano, T., Salerno, G., Burton, M., and Mather, T. A.: Sulphur dioxide fluxes from Mount Etna, Vulcano, and Stromboli measured with automated scanning ultraviolet spectrometer, J. Geophys. Res., 108, 2455, doi:10.1029/2002JB002261, 2003.

McGonigle, A. J. S., Oppenheimer, C., Tsanev, V. I., Saunder, S., Mulina, K., Tohui, S., Bosco, J., Nahou, J., Kuduon, J., and Taranu, F.: Sulphur dioxide fluxes from Papua New Guinea's volcanoes, Geophys. Res. Lett., 31, L08606, doi:10.1029/2004GL019568, 2004.

Nho, E.-Y., Le Cloarec, M.-F., Ardouin, B., and Tjetjep, W. S.: Source strength assessment of volcanic trace elements emitted from the Indonesian arc, J. Volcanol. Geoth. Res., 74, 121-129. 1996.

Penner, J. E., Andreae, M., Annegarn, H., Barrie, L., Feichter, J., Hegg, D., Jayaraman, A., Leaitch, R., Murphy, D., Nganga, J., and Pitari, G.: Aerosols, their Direct and Indirect Effects, in: Climate Change 2001: The Scientific Basis, edited by: Houghton, J. T., Ding, Y., Griggs, D. J., Noguer, M., Van der Linden, P. J., Dai, X., Maskell, K., and Johnson, C. A., Report to Intergovernmental Panel on Climate Change from the Scientific Assessment Working Group (WGI), Cambridge University Press, 289-416, 2001.

Platt, U. and Stutz, J.: Differential Optical Absorption Spectroscopy: principles and applications, XV 597, Springer, Heidelberg, 272 pp., 2008. 
Reed, M. H. and Spycher, N. F.: Calculation of high temperature $\mathrm{pH}$ and mineral equilibria in hydrothermal water, with application to geochemistry and studies of boiling and dilution, Geochim. Cosmochim. Ac., 48, 1479-1492, 1984.

Reed, M. M. and Spycher, N. F.: Boiling, cooling, and oxidation in epithermal systems: a numerical modeling approach, Rev. Econ. Geol., 2, 249-272, 1985.

Shinohara, H.: Excess degassing from volcanoes and its role on eruptive and intrusive activity, Rev. Geophys., 46, RG4005, doi:10.1029/2007RG000244, 2008.

Simkin, T., Siebert, L., McClelland, L., Bridge, D., Newhall, C., and Latter, J. H.: Volcanoes of the World: A Regional Directory, Gazetteer, and Chronology of Volcanism During the Last 10,000 Years, Hutchinson Ross, Stroudsburg, PA, 1981.

Spiro, P. A., Jacob, D. J., and Logan, J. A.: Global Inventory of Sulfur Emissions with $1^{\circ} \times 1^{\circ}$ Resolution, J. Geophys. Res., 97, 6023-6036, 1992.

Spycher, N. F. and Reed, M. H.: Evolution of a Broadlands-type epithermal ore fluid along alternative P-T paths: implications for the transport and deposition of base, precious, and volatile metals, Econ. Geol., 84, 328-359, 1989.

Stevenson, D. S., Johnson, C. E., Collins, W. J., and Derwnt, D. R.: The tropospheric sulphur cycle and the role of volcanic $\mathrm{SO}_{2}$, in: Volcanic Degassing, edited by: Oppenheimer, C., Pyle, D. M., and Barclay, J., Geol. Soc. London, Special Publications, 213, 295-305, 2003.
Stoiber, R. E., Malinconico Jr., L. L., Williams, S. N.: Use of the correlation spectrometer at volcanoes, in: Forecasting Volcanic Events, edited by: Tazieff, H. and Sabroux, J. C., Elsevier, New York, 425-444, 1983.

Stoiber, R. E., Williams, S. N., and Huebert, B.: Annual contribution of sulfur dioxide to the atmosphere by volcanoes, J. Volcanol. Geoth. Res., 33, 1-8, 1987.

Stutz, J. and Platt, U.: Numerical analysis and estimation of the statistical error of differential optical absorption spectroscopy measurements with least-squares methods, Appl. Optics, 35, 60416053, 1996.

Symonds, R. B., Gerlach, T. M., Reed, M. H.: Magmatic scrubbing: implications for volcano monitoring, J. Volcanol. Geoth. Res. 108, 303-341, 2001.

Tsanev, V. I.: A collection of JScripts for retrieval of gas column amounts using DOAS methodology, available at: http: //www.geog.cam.ac.uk/research/projects/doasretrieval/ (last access: 30 September 2013), 2008.

Voigt, S., Orphal, J., Bogumil, K., and Burrows, J. P.: The Temperature Dependence (203-293 K) of the Absorption Cross-Sections of $\mathrm{O}_{3}$ in the $230-850 \mathrm{~nm}$ region Measured by Fourier-Transform Spectroscopy, J. Photoch. Photobio. A, 143, 1-9, 2001. 